\title{
Abrasive Machining of Ti6Al4V Alloy
}

Radek Lattner ${ }^{1}$, František Holešovský ${ }^{1}$, Tomáš Karel ${ }^{2}$, Michal Lattner $^{1}$

${ }^{1}$ Department of Technology and Material Engineering, Faculty of Production Technology and Management, J. E. Purkyně University, Pasteurova 1, 40001 Ústí nad Labem, E-mail: lattnerr@fvtm.ujep.cz, holesovsky@fvtm.ujep.cz, lattner@fvtm.ujep.cz

${ }^{2}$ Bosch, Roberta Bosche 2678, 37004 České Budějovice

This paper deals with evaluation of ground surface of Ti6Al4V alloy according to surface roughness. This titanium alloy has large scale of utilization, it is used for implants and surgical instruments. Significant problem during grinding of titanium alloys is generation of large amount of heat which can cause surface cracks, increase hardness of surface and increase of tool wear. Each specimen was ground on surface grinding machine by diferent cutting conditions. The roughness parameters $\mathrm{Ra}, \mathrm{Rq}, \mathrm{Rz}$ and $\mathrm{Rt}$ were measured five times on each specimen in each axis (axis $y$ - direction of feed rate, axis $x$ - perpendicular to the feed rate). The values of the roughness parameters (Ra, Rq, Rt and Rz) are presentated in the graphs where we can see the influence of the cutting conditions on these roughness parameters.

Keywords: grinding, titanium alloy, roughness, abrasive

\section{Acknoledgement}

This article was created with the support of Student Grant Competition no. 4820215000601.

\section{References}

[1] MACEK, K. et al. (2002). Nauka o materiálu. Praha, ČVUT, 209 s.

[2] JANOVEC, J., CEJP, J., STEIDL, J. (2001). Prespektivní materiály. Praha, ČVUT, 135 s.

[3] MACEK, K. (1991). Kovové materiály. Praha, ČVUT, 157 s.

[4] MASLOV, J. N. (1979). Teorie broušení. Praha, SNTL, 248 s.

[5] ROWE, W. B. (2009). Principles of Modern Grinding Technology. UK, William Andrew, $416 \mathrm{s.}$

[6] MALKIN, S., GUO, C. (2008). Grinding Technology: Theory and Applications of Machining with Abrasives. New York: IndustrialPress, $372 \mathrm{~s}$.

[7] MARINESCU, I. D., et al. (2007). Handbook of Machining with Grinding Wheels. New York: CRCPress, 593 s.

[8] KLOCKE, F. (2009). Manufacturing Processes 2: Grinding, Honing, Lapping. Berlin: Springer, 433 s.

[9] VASILKO, K. (2001). Obrábanie titánu a jeho zliatin. Prešov: FVT, 120s.

[10]KUMAR, K. V. (1990). Superabrasive Grinding of Titanium Alloys. In: Conference Papers - International Grinding Conference, 4th, 117 pp. Michigan: SME.

[11]HOLEŠOVSKÝ, F., HRALA, M. (2002). Broušení kovů a keramiky - Drsnost povrchu a jeho profil. Strojirenská technologie, no. 7, s. 18-25

[12]HOLEŠOVSKÝ, F. (2005). Výzkum a nové poznatky broušení. Strojírenská technologie. č. 10, s. 51-55.

[13]MICHNA, Š. MICHNOVÁ, L. (2014). Neželezné kovy. PrinPoint, Praha, ISBN: 978-80-260-7132-7

[14] Katalogový list produktu. LEXT OLS 3000. Japonsko: Olympus. 2004. 16s. Dostupné z www: http://www.iolympus.cz/mikroskopy/prospekty/LEXT\%20OLS3000.pdf>.

[15]N.I. GALANIS, A.P. MARKOPOULOS, I.D. GIANNAKOPOULOS, D.E. MANOLAKOS. (2013). Manufacturing of Femoral Heads from Ti-6Al-4V Alloy with High Speed Machining: 3D Fiinite Element Modelling Experimental Validation. In: Manufacturing technology. Vol. 13, No. 4, p. 437-444, ISSN: 1213-2489. 